Marquette University

e-Publications@Marquette

Theology Faculty Research and Publications

Theology, Department of

$1-1-2012$

\title{
Demons of Change: Transformational Role of the Antagonist in the Apocalypse of Abraham
}

Andrei Orlov

Marquette University, andrei.orlov@marquette.edu

Published version. "Demons of Change: Transformational Role of the Antagonist in the Apocalypse of Abraham," in A Teacher for All Generations. Ed. Eric F. Mason. Leiden: Brill, 2012: 601-619. DOI. (C) 2012 Brill. Used with permission. 


\section{DEMONS OF CHANGE: \\ THE TRANSFORMATIONAL ROLE OF THE ANTAGONIST \\ IN THE APOCALYPSE OF ABRAHAM*}

Andrei A. Orlov

The Apocalypse of Abraham, a Jewish pseudepigraphon written in the first centuries C.E., baffles its readers' imaginations with a plethora of sacerdotal motifs. From its very first lines, this enigmatic text strives to portray young Abraham and his relatives as cultic servants performing priestly duties in a sanctuary filled with idolatrous statues. The readers of the text soon recognize that its peculiar cultic concerns permeate the fabric of the entire pseudepigraphon. Indeed, its authors appear to assign specific cultic roles to almost all of the story's characters. As the narrative progresses, and the deity removes the young hero of the faith from the defiled house of worship and sets him on a celestial journey to the true sanctuary in heaven, new characters endowed with sacerdotal functions begin to enter the story.

The most spectacular cultic responsibilities are given to Abraham's celestial guide, the angel Yahoel, whom the text envisions as the heavenly high priest and the celestial choir-master of the living creatures. Both his peculiar liturgical duties vis-à-vis the throne room's angelic creatures and his bold access to the divine presence reveal Yahoel's status as a very special celebrant ministering in the celestial sanctuary. As has been noted before, some of Yahoel's actions are reminiscent of the cultic acts of the high priest, that singularly unique sacerdotal servant who was able to enter the divine presence in the Holy of Holies on Yom Kippur. Indeed it seems, in light of the striking panoply of priestly motifs in the Apocalypse of Abraham, that its authors had not forgotten this central sacerdotal ordinance of the Jewish tradition-a major cultic event laden with portentous revelatory opportunities. As the story develops, and Yahoel leads his human apprentice, Abraham, into the celestial Holy of Holies located in the upper heaven, the cluster

\footnotetext{
* It is a source of great pleasure to be able to contribute an article for a volume honoring Professor James VanderKam, a scholar from whom I have learned so much.
} 
of motifs pertaining to this special atoning rite become more and more distinctive. Scholars have noted previously that the instructions Yahoel conveys to Abraham invoke the memory of peculiar symbolic actions and rituals which took place on the Day of Atonement. ${ }^{1}$ Moreover, it has even been suggested that in chapters 13 and 14 Yahoel performs the climactic action of the atoning ceremony on Yom Kippur, that is, the enigmatic scapegoat ritual, by which impurity was transferred onto a goat named Azazel and then, through him, dispatched into the wilderness. $^{2}$

Yet despite striking similarities with Yom Kippur traditions found in biblical and rabbinic accounts, the authors of the Slavonic apocalypse strive to refashion the ancient rite in accordance with a new apocalyptic outlook, which sees the earthly version of the atoning ritual as a reflection of celestial and eschatological realities. In this perspective, one may recognize a new cosmic dimension of the atoning ordinance, which is envisioned in the Slavonic text as the eschatological Yom Kippur. That we find this emphasis on the heavenly and eschatological dimensions of the sacerdotal symbolism in a transitional text like the Apocalypse of Abraham is no coincidence. It was written during

${ }^{1}$ See, for example, C. Fletcher-Louis, "The Revelation of the Sacral Son of Man," in Auferstehung-Resurrection. The Fourth Durham-Tübingen Research Symposium: Resurrection, Transfiguration and Exaltation in Old Testament, Ancient Judaism, and Early Christianity (Tübingen, 1999) (ed. F. Avemarie and H. Lichtenberger; Tübingen: Mohr Siebeck, 2001), 282; L. L. Grabbe, "The Scapegoat Tradition: A Study in Early Jewish Interpretation," JSJ 18 (1987): 165-79, esp. 157; R. Helm, “Azazel in Early Jewish Literature," Andrews University Seminary Papers 32 (1994): 217-226, esp. 223; B. Lourié, "Propitiatorium in the Apocalypse of Abraham," in The Old Testament Apocrypha in the Slavonic Tradition: Continuity and Diversity (ed. L. DiTommaso and C. Böttrich, with the assistance of M. Swoboda; TSAJ 140; Tübingen: Mohr Siebeck, 2011), 267-77; A. A. Orlov, "Eschatological Yom Kippur in the Apocalypse of Abraham. Part I. The Scapegoat Ritual," in Symbola Caelestis. Le symbolisme liturgique et paraliturgique dans le monde chrétien (Scrinium 5; ed. A. Orlov and B. Lourié; Piscataway: Gorgias Press, 2009), 79-111; D. Stökl Ben Ezra, "Yom Kippur in the Apocalyptic Imaginaire and the Roots of Jesus' High Priesthood: Yom Kippur in Zechariah 3, 1 Enoch 10, 11QMelkizedeq, Hebrews and the Apocalypse of Abraham 13," in Transformations of the Inner Self in Ancient Religions (ed. J. Assman and G. Stroumsa; Leiden: Brill, 1999), 349-366; idem, "The Biblical Yom Kippur, the Jewish Fast of the Day of Atonement and the Church Fathers," StPatr 34 (2002): 493-502; idem, The Impact of Yom Kippur on Early Christianity: The Day of Atonement from Second Temple Judaism to the Fifth Century (WUNT 163; Tübingen: Mohr Siebeck, 2003), 94.

${ }^{2}$ Orlov, "Eschatological Yom Kippur in the Apocalypse of Abraham. Part I. The Scapegoat Ritual," 79-111. 
a unique period in Jewish history, when apocalyptic authors, faced with a wide array of challenges stemming from the destruction of the Jerusalem Temple, embraced various theological alternatives for preserving and perpetuating traditional priestly practices. When it envisions heaven as the true place of worship, and depicts Abraham as an adept of the heavenly priestly praxis entering the celestial Holy of Holies, the Apocalypse of Abraham evinces one such sacerdotal option.

Veiled symbolism, which reveals both apocalyptic and sacerdotal realities, accompanies the seer's cultic entrance into heaven. Thus in the Apocalypse of Abraham, as in many other Jewish pseudepigraphical narratives, the hero's entrance into the sacred realm coincides with his peculiar transformation as celebrant of the celestial liturgy. This metamorphosis, hinted at symbolically via the change in Abraham's ontological garments, was often taken to mark the transition from an earthly to a celestial condition. Here, as in the Yom Kippur ordinance, the metamorphosis of the celebrant's wardrobe is the pinnacle of transformational experience.

Although previous studies have explored many facets of the Yom Kippur imagery in the Apocalypse of Abraham, sufficient attention has not yet been paid to the peculiar metamorphoses which the story's (human and angelic) protagonists and antagonists seem to experience in the course of their participation in the drama of the eschatological Yom Kippur ritual. The present study aims to further explore the Yom Kippur traditions in the Slavonic apocalypse by paying special attention to the transformational aspects of this enigmatic atoning ritual.

\section{Lost AtTire}

The Apocalypse of Abraham can be divided into two parts. The first, a "haggadic" section (chs. 1-8), depicts the young hero of the faith as a paladin against his father Terah's idolatrous statues. The second, an "apocalyptic" section (which occupies the work's remaining chapters), describes Abraham as he prepares for his heavenly journey, progresses into the abode of the deity, and acquires eschatological mysteries. This second section unveils one of the most important dynamics to be found in the Jewish apocalyptic accounts. In this conceptual framework, both positive and negative characters progress into the respective realms of their eschatological opponents, and frequently assume the roles and 
offices of their counterparts. ${ }^{3}$ In such accounts, a seer and his demoted opponent(s) often confront each other on their journeys to their new habitats. ${ }^{4}$

Apocalypse of Abraham 13, where Abraham encounters his eschatological antagonist in the form of the fallen angel Azazel, may represent a crossroads in the text of this dynamic of exaltation and demotion. In the course of this encounter, Abraham's angelus interpres, Yahoel, informs both parties that the celestial garment of the demoted angel must now be transferred to a new owner-the translated hero of the faith. Thus Apoc. Ab. 13:7-14 reads:

Reproach is on you, Azazel! Since Abraham's portion is in heaven, and yours is on earth, since you have chosen it and desired it to be the dwelling place of your impurity.... For behold, the garment which in heaven was formerly yours has been set aside for him, and the corruption which was on him has gone over to you. (Apoc. Ab. 13:7-14) ${ }^{5}$

The pivotal transformational motif invoked in this passage-namely, the promise of new attire to the translated hero-signifies not merely a rather unusual expansion of the patriarch's wardrobe, but his ontological transition from the form of a human being to the status of celestial citizen. Such endowments with celestial attire are not unusual in apocalyptic literature. Seers often receive angelic garments. In 2 Enoch 22, for example, Enoch is clothed with a luminous angelic garment, which makes his body similar to the glorious bodies of the angelic servants. Such a metamorphosis is of great anthropological significance:

3 This peculiar dynamic of apocalyptic accounts is already present in early Enochic booklets, where the antagonists represented by the fallen angels assume a wide array of human roles on earth, while a human protagonist-Enoch-assumes their celestial and priestly offices in the heavenly realm.

${ }_{4}$ One of the instances of such an encounter between exalted hero and demoted antagonists can be found in 2 Enoch, where the seventh antediluvian patriarch meets, on his celestial journey, a group of incarcerated watchers in the second heaven. On this tradition see A. Orlov, "The Watchers of Satanail: The Fallen Angels Traditions in 2 (Slavonic) Enoch," in Divine Manifestations in the Slavonic Pseudepigrapha (ed. Orlov; Orientalia Judaica Christiana 2; Piscataway: Gorgias Press, 2009), 237-68; repr. in The Watchers in Jewish and Christian Traditions (ed. A. K. Harkins, J. Endres, and K. Coblentz Bautch; CBQMS; Washington D.C.: Catholic Biblical Association, forthcoming 2012).

${ }_{5}$ All citations of Apoc. Ab. in this essay are taken from the translation by A. Kulik in Retroverting Slavonic Pseudepigrapha: Toward the Original of the Apocalypse of Abraham (SBL Text-critical Studies 3; Atlanta: Society of Biblical Literature, 2004; repr. Leiden: Brill, 2005), here 20. 
it signals a return to the original luminosity the first humans lost after their transgression in Eden.

In the Apocalypse of Abraham the hero's transition also seems to invoke the memory of the protological story in which the luminous clothes of the heavenly beings were exchanged for garments of skin. Abraham's endowment with angelic garments may, therefore, signal an eschatological return to the Protoplast's original condition. Several of the text's students have, in fact, noted this possibility. Louis Ginzberg, for one, suggested the possible Adamic background and pointed to parallels in the targumic materials and in Pirqe Rabbi Eliezer $20{ }^{6}$ Indeed, the transference of a garment from the demoted angelic antagonist to an exalted human protagonist is an important theme throughout the Adamic lore.

Some of the currents within this tradition entertain the unusual notion that even the original, luminous garments of the first humans had come from a demoted celestial being. This can be seen, for example, in Targum Pseudo-Jonathan on Gen 3:21, a passage which treats the etiology of the first humans' luminous attire. According to this targumic interpretation, the original humans were endowed with luminous garments that had been stripped from the serpent:

And the Lord God made garments of glory for Adam and for his wife from the skin which the serpent had cast off (to be worn) on the skin of their (garments of) fingernails of which they had been stripped, and he clothed them. ${ }^{7}$

Later midrashim are also aware of the enigmatic provenance of the protoplasts' luminous garments; thus, for example, Pirqe Rabbi Eliezer 20 reads:

Rabbi Eliezer said: From skins which the serpent sloughed off, the Holy One, blessed be He, took and made coats of glory for Adam and his wife, as it is said, "And the Lord God made for Adam and his wife coats of skin, and clothed them."

${ }^{6}$ See L. Ginzberg, “Apocalypse of Abraham," Jewish Encyclopedia 1:91-92; esp. 92.

7 Targum Pseudo-Jonathan: Genesis (trans. M. Maher, M.S.C.; AB, 1B; Collegeville: Liturgical Press, 1992), 29. Later rabbinic traditions also hold that the glorious garments of Adam and Eve were made from the skin of the female Leviathan.

${ }^{8}$ Pirke de Rabbi Eliezer (trans. G. Friedlander; 2d ed.; New York: Hermon Press, 1965), 144. 
These passages seem to unveil the dynamic of exaltation and demotion noted above; they suggest that the protagonist's apotheosis, signaled through his acquisition of luminous attire, comes as a result of the denigration of the erstwhile favorite, who is now stripped of his exalted status. While the new possessors of exalted status are drawn, by the will of God, to their dignified abodes, their antagonistic counterparts are forced into exile from their elevated domiciles.

The tradition of the first humans' clothes of glory, mentioned in Targum Pseudo-Jonathan and Pirqe Rabbi Eliezer, is important for our study. The motif of Abraham's endowment with a garment stripped from the fallen angel cannot be properly understood without exploring the array of traditions associated with Adamic clothing metaphors-a seminal conceptual cluster whose roots can be traced already to some biblical developments. ${ }^{9}$

\section{The Glory of the Fallen Angel}

The biblical Adamic tradition represents, in many ways, the formative bedrock of the later apocalyptic and mystical developments; this tradition centers on the eschatological re-clothing of the translated patriarchs and prophets, who change the attire of their ontological conditions often at their opponents' expense.

In the Adamic lore one also finds the roots of the peculiar etiology, noted above, according to which the first humans themselves received their unique status, manifested in luminous garments, as a result of the demotion of an exalted angelic being which fell out of favor with the deity. In these traditions, the Protoplast literally takes the place, glory, and garments of the demoted angelic antagonist. One of the early specimens of such a tradition can be found again in the Primary Adam Books, where Satan's removal from his special glorious place is set in conceptual symmetry with the creation and exaltation of Adam. Moreover, the very fact of the first human's entrance into the world serves, in this text, as the reason for Satan's dismissal; several versions of the Life of Adam and Eve connect Satan's removal from his exalted

\footnotetext{
${ }^{9}$ One such cryptic allusion to the Protoplast's glorious garments can possibly be found in Ezekiel 28, which tells the story of a glorious being, originally installed in the Garden of Eden but then forcefully expelled from this lofty location. The text describes the peculiar garment of this being as decorated with precious stones and gold.
} 
dwelling with his refusal to bow down before the deity's newly created favorite.

Thus, for example, in the Armenian version of the Life of Adam and Eve 12:1-16:2, the infamous celestial rebel himself describes the reason for his dramatic exile from the throne of the cherubim and the dwelling of light:

Satan also wept loudly and said to Adam. "All my arrogance and sorrow came to pass because of you; for, because of you I went forth from my dwelling; and because of you I was alienated from the throne of the cherubs who, having spread out a shelter, used to enclose me; because of you my feet have trodden the earth.... Thereupon, God became angry with me and commanded to expel us from our dwelling and to cast me and my angels, who were in agreement with me, to the earth; and you were at the same time in the Garden. When I realized that because of you I had gone forth from the dwelling of light and was in sorrows and pains." ${ }^{10}$

This enigmatic passage graphically reveals the origins of the longlasting drama of competition and revenge that will later overshadow the whole history of humankind. Yet it also hints at the mysterious dynamics of the celestial realm, a hierarchical world where the rise of the deity's new favorite almost inevitably leads to demise of the old, who now must surrender his unique status, reflected in his garment, to his replacement. It would seem that this unique wardrobe, which signifies the distinctive status of the servant vis-à-vis the Divinity, cannot be divided among many.

In the Life of Adam and Eve, Satan repeatedly describes his original condition through metaphors of glory and light. These are precisely the formulae often used in the Primary Adam Books to describe first humans' celestial attire. Thus, in the Latin version of the aforementioned text (12:1-16:2), the adversary describes his lost condition through the symbolism of glory:

O Adam, all my enmity, jealousy, and resentment is towards you, since on account of you I was expelled and alienated from my glory ( $g l o-$ ria mea), which I had in heaven in the midst of the angels. Then the Lord God grew angry with me and sent me forth with my angels from our glory (gloria nostra). On account of you we were expelled from our dwelling into this world and cast out upon the earth. Immediately we

\footnotetext{
${ }^{10}$ A Synopsis of the Books of Adam and Eve (ed. G. A. Anderson, M. E. Stone; 2d rev. ed.; SBLEJL 17; Atlanta: Scholars Press, 1999), 15E-18E.
} 
were in grief, since we had been despoiled of so much glory (gloria), and we grieved to see you in such a great happiness of delights. ${ }^{11}$

The demoted antagonist's alienation from his former glorious state, then, is several times set in parallel to the exaltation and gifts given to the Protoplast: "since we had been despoiled of so much glory (gloria), and we grieved to see you in such a great happiness of delights."12

\section{Priestly Garments of Abraham}

It is now time to return to the Apocalypse of Abraham, where the transference of Azazel's angelic garment to the patriarch reflects similar conceptual developments. Scholars have previously noted that the details in the enigmatic story of Abraham's changing wardrobe also seem to invoke traditions from several biblical prophetic texts. Recall that in Apocalypse of Abraham 13 Abraham is caught up in an arcane interaction between the demon Azazel and the angel Yahoel. Azazel attempts to discourage Abraham from ascending into the celestial realm, warning him that he will be destroyed there by fire, while Yahoel tries to strengthen the will of Abraham and rebuke the demon.

That fact that Abraham stands between two celestial figures, one of whom is a good angel and the other his evil counterpart, is reminiscent of the account in Zechariah 3, where the high priest Joshua is depicted as standing between two spirits. ${ }^{13}$ In Zechariah, as in the

${ }^{11}$ Ibid., 15-18E. On the Latin version of the Primary Adam Books, see also W. Meyer, "Vita Adae et Evae," Abhandlungen der königlichen Bayerischen Akademie des Wissenschaften, Philosoph.-philologische Klasse 14 (1878): 185-250.

${ }_{12}$ A Synopsis of the Books of Adam and Eve, 18-18E.

${ }_{13}$ Marc Philonenko, analyzing the symmetrical nature of the positions of Yahoel and Azazel in the Apocalypse of Abraham, notes the peculiarity of the interaction between these two spirits, one good and one malevolent. He notices that their contention does not occur directly but rather through a medium of a human beingAbraham. In the Slavonic pseudepigraphon, Abraham thus becomes a place of the battle between two spiritual forces. Philonenko sees in such struggle a peculiar mold of the dualism present also in a Qumran material known to scholars as the Instruction on the Two Spirits (1QS 3:13-4:26), where the Prince of Lights and the Angel of Darkness are fighting in the heart of man. Philonenko-Sayar and Philonenko, L'Apocalypse d'Abraham. Introduction, texte slave, traduction et notes (Semitica 31; Paris: Librairie Adrien-Maisonneuve, 1981), 31-32. The unique position of Abraham, standing between Azazel and the Name of God (Yahoel), evokes the memory of the Yom Kippur ritual, where the high priest stood between two earthly counterparts of these celestial realities: the scapegoat and the goat for the Name of the Lord. See 
Slavonic apocalypse, distinctive priestly concerns are conflated with the motif of the change of garments; thus Zechariah 3-4 reads:

Then he showed me the high priest Joshua standing before the angel of the Lord, and Satan standing at his right hand to accuse him. And the Lord said to Satan, "The Lord rebuke you, O Satan! The Lord who has chosen Jerusalem rebuke you! Is not this man a brand plucked from the fire?" Now Joshua was dressed with filthy clothes as he stood before the angel. The angel said to those who were standing before him, "Take off his filthy clothes." And to him he said, "See, I have taken your guilt away from you, and I will clothe you with festal apparel." And I said, "Let them put a clean turban on his head." So they put a clean turban on his head and clothed him with the apparel; and the angel of the Lord was standing by. Then the angel of the Lord assured Joshua, saying "Thus says the Lord of hosts: If you will walk in my ways and keep my requirements, then you shall rule my house and have charge of my courts, and I will give you the right of access among those who are standing here. Now listen, Joshua, high priest, you and your colleagues who sit before you! For they are an omen of things to come: I am going to bring my servant the Branch. For on the stone that I have set before Joshua, on a single stone with seven facets, I will engrave its inscription, says the Lord of hosts, and I will remove the guilt of this land in a single day. On that day, says the Lord of hosts, you shall invite each other to come under your vine and fig tree." The angel who talked with me came again, and wakened me, as one is wakened from sleep. He said to me, "What do you see?" And I said, "I see a lampstand all of gold, with a bowl on the top of it; there are seven lamps on it, with seven lips on each of the lamps that are on the top of it. And by it there are two olive trees, one on the right of the bowl and the other on its left." (NRSv)

In this striking passage we find a description of the priestly initiation in which a high priest receives the pure garment. This invokes the memory of other cultic initiations in Jewish apocalyptic texts, like Testament of Levi 8 and 2 Enoch 22, where the exalted patriarchs receive priestly robes. Like Zechariah 3, these texts allude to the anthropological significance of priestly initiation, which symbolizes return to the original condition of the Protoplast by stripping the filthy garments of fallen humanity.

The parallels between Zechariah 3-4 and the Apoc. Ab. 13-14 allow us to better understand the sacerdotal context of the Slavonic account, and its connection with the Day of Atonement. Indeed, as Daniel Stökl

R. Rubinkiewitz, Die Eschatologie von Henoch 9-11 und das Neue Testament, 101-102; 110-113; Stökl Ben Ezra, The Impact of Yom Kippur on Early Christianity, 94. 
Ben Ezra has observed, in comparison it seems that the Apocalypse of Abraham develops the cultic imagery more decisively: "compared to Zechariah 3, the Apocalypse of Abraham embellishes the Yom Kippur imagery." 14 Unlike Zechariah, where the soiled garment of the priestly figure is simply exchanged for the pure one, in the Apocalypse of Abraham the transformational pattern appears to be more radical; it involves the memory of the specific context of the Yom Kippur ritual, where the scapegoat took upon itself humanity's defilement. In the Apocalypse of Abraham, the priestly initiate's soiled garments are not simply, as in Zechariah, exchanged for pure ones. They are transferred to Azazel. This evokes the cathartic nature of the Yom Kippur ritual, in which the sin of humanity was transferred to the scapegoat.

The Apocalypse of Abraham 13 graphically underlines this exchange:

And he said to him, "Reproach is on you, Azazel! Since Abraham's portion is in heaven, and yours is on earth.... For behold, the garment which in heaven was formerly yours has been set aside for him, and the corruption which was on him has gone over to you." (Apoc. Ab. 13:7-14)

David Halperin previously reflected on the importance of the motif of the wardrobe-exchange between positive and negative characters:

[W]e see here the theme, which we have already met in the stories of Enoch in the Book of the Watchers and of Adam in the "Apocalypse of Moses," of the exaltation of the human and the degradation of the angel corresponding to each other and to some extent depending on each other. If Azazel can persuade Abraham not to make his ascent, he will perhaps be able to keep his own privileged status. ${ }^{15}$

It should be stressed again that the connections between the initiation scenes in Apoc. Ab. and Zechariah are important since they help to illumine the priestly nature of the peculiar transitions that the hero of the faith undergoes immediately before his entrance into the throne room in the upper heaven, the sacred locale envisioned in the text as the celestial counterpart of the earthy Holy of Holies. ${ }^{16}$

${ }^{14}$ Stökl Ben Ezra, The Impact of Yom Kippur on Early Christianity, 94.

${ }^{15}$ Halperin, The Faces of the Chariot, 111.

${ }^{16}$ The previous studies of the Apocalypse of Abraham suggested that the seer's entrance into the celestial realm reveals the cultic dimension and is envisioned as a visitation of the heavenly temple. In this respect, Himmelfarb (Ascent to Heaven, 66) observes that:

the heaven of the Apocalypse of Abraham is clearly a temple. Abraham sacrifices in order to ascend to heaven, then ascends by means of the sacrifice, and joins 
Scholars have lamented the apparent dearth of decisively priestly transformation in the Apocalypse of Abraham..$^{17}$ Yet I think Martha Himmelfarb is right when she suggests that the promise of a garment given to a seer immediately before his entrance into heaven fulfills, in this text, the function of the actual re-clothing. Although "Abraham does not undergo a transformation as explicit as that of Enoch, Isaiah, or Zephaniah," he "is never actually provided with a garment"; rather, "he has been promised one." 18

\section{From Sacrificial Animal to Fallen Angel}

On the basis of our previous investigation it seems that the transformation of the patriarch in the Apocalypse of Abraham depends in many ways on the peculiar changes affecting his antagonistic counterpartthe fallen angel Azazel. The exaltation of the one depends on the demotion of the other, who had once prospered in an elevated domicile but is now forcefully expelled from this domain. As with entrance into the upper realm, removal too is laden with profound changes in the spiritual and physical states of the characters. Like the heroes of the apocalyptic accounts who undergo spectacular metamorphoses preparing them for the novel conditions of their newly acquired celestial domains, the metamorphoses of the antagonists have an ontological significance, foreshadowing the fate of the deity's former favorites

in the heavenly liturgy to protect himself during the ascent.... The depiction of heaven as a temple confirms the importance of the earthly temple. The prominence of the heavenly liturgy lends importance to the liturgy of words on earth, which at the time of the apocalypse provided a substitute for sacrifice, a substitute that in the apocalypse's view was to be temporary.

17 Yet the repeated references to a seer's encounter with fire appear to be significant for the authors of the pseudepigraphon, who envision fire as a theophanic substance surrounding the very presence of the deity. Thus, later in the text Abraham's transition into the divine realm is described as his entering into the fire. Cf., for example, Apoc. $A b$. 15:3: "And he carried me up to the edge of the fiery flame"; also Apoc. Ab. 17:1: "And while he was still speaking, behold, a fire was coming toward us round about, and a sound was in the fire like a sound of many waters, like a sound of the sea in its uproar." Could the promise of a celestial garment to the patriarch in the Apocalypse of Abraham signify here, as in many other apocalyptic accounts, that his "mortal" body must be "altered" in the fiery metamorphosis? On this point, it should be noted that the entrance of a visionary into a fire and his fiery transformation represent common apocalyptic motifs found in texts ranging from Daniel 3 to 3 Enoch, where Enoch undergoes the fiery metamorphosis that turns him into the supreme angel Metatron.

${ }^{18}$ Himmelfarb, Ascent to Heaven, 64. 
now transported, by the will of the Creator, into the lower realms. From this negative transformation, often conveyed in detail in various pseudepigraphical accounts, readers gain insight into the peculiar refashioning of the celestial garments of the demoted antagonists who undergo transitions into new forms suited to their exilic realms.

By observing these ominous changes in the antihero (who, paradoxically, mocks the protagonist's metamorphosis) readers of the visionary accounts gaze into the logic of a kind of negative transformational mysticism. ${ }^{19}$ This process plays an important role in apocalyptic stories as an apophatic reaffirmation of the hero's transformative motifs.

The complexity of the negative routine endured by the demoted agents should not be underestimated. The acquisition of the novel ontological garments bestowed on an antagonist is often surrounded with the most recondite and puzzling imagery to be found in the apocalyptic accounts. These accounts offer the eyes of their beholders a plethora of cryptic depictions, in which the composite physiques of the demoted heroes often represent a bizarre mixture of demonic and heavenly attributes. This hybrid nature of the negative heroes' visible manifestations suggests that, despite their exile into the lower realms, these formerly celestial creatures were never intended to function as the harmonious inhabitants of their newly acquired environments; rather, they were predestined to become the agents of a foreboding, corrupting change-a change often fatal to the realms of their exile.

In this respect, it is no coincidence that in the Slavonic apocalypse (as in many other pseudepigraphical accounts dealing with the demotion of fallen angels) so much attention should be spent on depictions of Azazel's various transitional shapes, the portrayals that represent creative improvisations on the theme of the corruption of an antagonist's original celestial form. Thus already in his debut at Apoc. Ab. 13, Azazel is designated as an "impure bird," a sobriquet which, in the peculiar symbolic code of the apocalypse's pteromorphic angelology, points to the corruption of his celestial form. ${ }^{20}$ This reference to an angelic form of the antagonist brings us again to the cluster of sacerdotal motifs associated with apocalyptic reinterpretation of the Yom Kippur festival.

19 On transformational mysticism, see C. R. A. Morray-Jones, "Transformational Mysticism in the Apocalyptic-Merkabah Tradition," JJS 43 (1992): 1-31.

${ }^{20}$ On the pteromorphic angelology of the Apocalypse of Abraham, see A. Orlov, "The Pteromorphic Angelology of the Apocalypse of Abraham," CBQ 72 (2009): 830-42. 
It has been noted that the sacerdotal context of the atoning ordinance seems to affect the chief antagonist's complex profile in the Slavonic apocalypse. In this text, allusions to Yom Kippur seem to have been reshaped deeply by the Enochic apocalyptic reinterpretation of the scapegoat ritual; its antagonist, the scapegoat Azazel, is envisioned not as a sacrificial animal but as a demoted heavenly being. In the Book of the Watchers, the scapegoat rite receives a striking angelological reinterpretation; it merges the peculiar dynamic of the sacrificial ritual with the story of its main antagonist, the fallen angel Asael.

1 Enoch 10:4-7 brings us to the very heart of this conceptual development:

And further the Lord said to Raphael: "Bind Azazel by his hands and his feet, and throw him into the darkness. And split open the desert which is in Dudael, and throw him there. And throw on him jagged and sharp stones, and cover him with darkness; and let him stay there for ever, and cover his face, that he may not see light, and that on the great day of judgment he may be hurled into the fire. And restore the earth which the angels have ruined, and announce the restoration of the earth, for I shall restore the earth." ${ }^{21}$

Scholars have previously pointed to the fact that several details in the account of Asael's punishment are reminiscent of the scapegoat ritual. ${ }^{22}$ Lester Grabbe's research outlines the specific parallels between

${ }^{21}$ All citations of 1 Enoch follow the translation by M. A. Knibb and E. Ullendorff, The Ethiopic Book of Enoch: A New Edition in the Light of the Aramaic Dead Sea fragments (2 vols.; Oxford: Clarendon; New York: Oxford University Press, 1978), 2:87-88.

${ }^{22}$ R. H. Charles, The Book of Enoch (Oxford: Clarendon, 1893), 72; D. Dimant, The Fallen Angels in the Dead Sea Scrolls and the Related Apocrypha and Pseudepigrapha (Ph.D. diss.; The Hebrew University in Jerusalem, 1974) [Hebrew]; idem, "1 Enoch 6-11: A Methodological Perspective," SBLSP (1978): 323-39; A. Geiger, "Zu den Apokryphen," Jüdische Zeitschrift für Wissenschaft und Leben 3 (1864): 196204; Grabbe, "Scapegoat Tradition: A Study in Early Jewish Interpretation," 165-79; P. Hanson, "Rebellion in Heaven, Azazel, and Euhemeristic Heroes in 1 Enoch 6-11," JBL 96 (1977): 195-233; Helm, "Azazel in Early Jewish Literature," 217-226; G. W. E. Nickelsburg, "Apocalyptic and Myth in 1 Enoch 6-11," JBL 96 (1977): 383-405; R. Rubinkiewicz, Die Eschatologie von Henoch 9-11 und das Neue Testament (trans. H. Ulrich; Osterreichische Biblische Studien 6; Klosterneuberg, 1984), 88-89; D. Stökl Ben Ezra, "Yom Kippur in the Apocalyptic Imaginaire and the Roots of Jesus' High Priesthood," 349-66; idem, The Impact of Yom Kippur on Early Christianity, 85-88; D. C. Olson, "1 Enoch," in Eerdmans Commentary on the Bible (ed. J. D. G. Dunn and J. W. Rogerson; Grand Rapids: Eerdmans, 2003), 904-41, esp. 910; C. Fletcher-Louis, "The Aqedah and the Book of Watchers (1 Enoch 1-36)," in Studies in Jewish Prayer (ed. R. Hayward and B. Embry; JSSSup 17; Oxford: Oxford University Press, 2005), 1-33, esp. 24. 
the Asael narrative in 1 Enoch and the wording of Leviticus 16, which include: (1) the similarity of the names Asael and Azazel; (2) the punishment in the desert; (3) the placing of sin on Asael/Azazel; and (4) the resultant healing of the land. ${ }^{23}$ Daniel Stökl Ben Ezra supports this position; he observes that "the punishment of the demon resembles the treatment of the goat in aspects of geography, action, time and purpose." 24

Moreover, the place of Asael's punishment, designated in 1 Enoch as Dudael, also recalls the rabbinic terminology used for the designation of the ravine of the scapegoat in subsequent interpretations of the Yom Kippur ritual. Several Qumran materials also seem to be aware of this angelological reinterpretation of the scapegoat figure; they choose to depict Azazel as the eschatological leader of the fallen angels, and thus incorporate him into the story of the Watchers' rebellion. ${ }^{25}$ Later rabbinic materials also link the sacrificial animal known from the scapegoat ritual to the story of the angelic rebels. ${ }^{26}$

${ }^{23}$ Grabbe, “The Scapegoat Tradition: A Study in Early Jewish Interpretation,” 153.

${ }^{24}$ Stökl Ben Ezra, The Impact of Yom Kippur on Early Christianity, 87.

25 Thus, 4Q180 1 i 1-10 reads: "Interpretation concerning the ages which God has made: An age to conclude [all that there is] and all that will be. Before creating them he determined [their] operations [according to the precise sequence of the ages,] one age after another age. And this is engraved on the [heavenly] tablets [for the sons of men,] [for] /[a]ll/ the ages of their dominion. This is the sequence of the son[s of Noah, from Shem to Abraham,] [unt]il he sired Isaac; the ten [generations...] [...] Blank [...] [And] interpretation concerning 'Azaz'el and the angels wh[o came to the daughters of man] [and s]ired themselves giants. And concerning 'Azaz'el [is written...] [to love] injustice and to let him inherit evil for all [his] ag[e...] [...] (of the) judgments and the judgment of the council of [...].' Lester Grabbe points to another important piece of evidence-a fragmentary text from the Book of Giants found at Qumran (4Q203). In this document the punishment for all the sins of the fallen angels is placed on Azazel. 4Q203 7 ii 1-7 reads: '[...]...[...] and [yo]ur power [...] Blank Th[en] 'Ohyah [said] to Hahy[ah, his brother...] Then he punished, and not us, [bu] t Aza[ze]l and made [him...the sons of] Watchers, the Giants; and n[o]ne of [their] be[loved] will be forgiven [...] ... he has imprisoned us and has captured yo[u];" (trans. taken from DSSSE, 1:411).

${ }^{26}$ Thus, for example, b. Yoma 67b records the following tradition: "The School of R. Ishmael taught: Azazel-[it was so called] because it obtains atonement for the affair of Uza and Aza'el," see The Babylonian Talmud. Yoma (ed. I. Epstein; London: Soncino, 1938), 316. On the afterlife of the Asael/Azazel tradition see A. Y. Reed, "From Asael and Šemihazah to Uzzah, Azzah, and Azael: 3 Enoch 5 (\$\$7-8) and Jewish Reception-History of 1 Enoch," JSQ 8 (2001) 105-36; idem, What the Fallen Angels Taught: The Reception-History of the Book of the Watchers in Judaism and Christianity (Ph.D. diss., Princeton University, 2002); idem, Fallen Angels and the history of Judaism and Christianity: The Reception of Enochic Literature (Cambridge: Cambridge University Press, 2005). 
Nevertheless, for our study the evidence of the early Enochic materials plays the most important role. In this respect, it is important to note that Asael's transformation into an animal is not limited solely to the Book of the Watchers. The same imagery also occupies an important place in the Animal Apocalypse, which depicts the fall of the Watchers as the mutation of stars into animals. ${ }^{27}$ In this Enochic booklet, the theriomorphism of the former angels is juxtaposed with the angelomorphism of Noah $^{28}$ and Moses, ${ }^{29}$ whose bodies undergo an inverse refashioning that transforms them from animals into humans. In the peculiar symbolic code of this apocalyptic work, this imagery signals the fact that Noah and Moses have thus acquired angelic bodies.

\section{The Garment of Darkness}

In the aforementioned passage about the binding of Asael during the sacrificial ritual in the desert (1 Enoch 10) we find an intriguing tradition about clothing the demon with darkness:

And throw on him jagged and sharp stones, and cover him with darkness; and let him stay there for ever, and cover his face, that he may not see light, and that on the great day of judgment he may be hurled into the fire. $(1 \text { En. 10:5-6) })^{30}$

The antagonist's covering with darkness is a pertinent motif for our investigation, as it may represent a conceptual correlative to the hero's clothing with light. Asael's covering with darkness appear to be a sort of counterpart to the garment of light which Enoch receives in heaven.

${ }^{27}$ Cf. 1 En. 86:1-4: “And again I looked with my eyes as I was sleeping, and I saw heaven above, and behold, a star fell from heaven, and its arose and ate and pastured amongst those bulls.... And again I saw in the vision and I looked at heaven, and behold, I saw many stars, how they came down and were thrown down from heaven to that first star, and amongst those heifers and bulls; they were with them, pasturing amongst them. And I looked at them and saw and behold, all of them let out their private parts like horses and began to mount the cows of the bulls, and they all became pregnant and bore elephants and camels and asses."

${ }_{28}$ Cf. 1 En. 89:1: "He was born a bull, but became a man, and built for himself a large vessel and dwelt on it."

${ }_{29}$ Cf. 1 En. 89:36: "And I looked there at the vision until that sheep became a man, and built a house for the Lord of the sheep, and made all the sheep stand in that house."

${ }^{30}$ Knibb, The Ethiopic Book of Enoch, 2:87-88. 
This ominous attire deprives its wearer from receiving the divine light-the source of life for all God's creatures.

That it is the face of the demon which is thus clothed with darkness may recall a series of transformational motifs involving, respectively, God's Panim and the panim of the visionary. This terminology is quite well known in Jewish apocalyptic literature. It does not merely designate the protagonist's or deity's visage per se, but symbolizes their complete covering with luminous attire.

\section{The IMPure Bird}

The Enochic demonological template factors significantly in the Apocalypse of Abraham, which envisions Azazel, like the Enochic antagonist, as a fallen angelic being. Indeed, the Azazel narrative of this later apocalypse reflects several peculiar details from the Enochic myth of the fallen angels as described in the Book of the Watchers. ${ }^{31}$ Thus Ryszard Rubinkiewicz has argued that

the author of the Apocalypse of Abraham follows the tradition of 1 Enoch 1-36. The chief of the fallen angels is Azazel, who rules the stars and most men. It is not difficult to find here the tradition of Genesis 6:1-4 developed according to the tradition of 1 Enoch. Azazel is the head of the angels who plotted against the Lord and who impregnated the daughters of men. These angels are compared to the stars. Azazel revealed the secrets of heaven and is banished to the desert. Abraham, as Enoch, receives the power to drive away Satan. All these connections show that the author of the Apocalypse of Abraham drew upon the tradition of 1 Enoch. ${ }^{32}$

In the Slavonic apocalypse, as in the Enochic and Qumran materials, Azazel is clearly no longer a sacrificial animal, but an angelic being. Already in his first appearance at Apoc. Ab. 13:3-4, the text depicts Azazel as an unclean or impure bird (Slav. nтиия нечистая). ${ }^{33}$ In the

${ }^{31}$ B. Philonenko-Sayar and M. Philonenko, L'Apocalypse d'Abraham. Introduction, texte slave, traduction et notes, 31-33; R. Rubinkiewicz, L'Apocalypse d'Abraham en vieux slave. Édition critique du texte, introduction, traduction et commentaire (Towarzystwo Naukowe Katolickiego Uniwersytetu Lubelskiego: Źródła i monografie 129; Lublin: Lublin Société des Lettres et des Sciences de l'Univ. Catholique de Lublin, 1987), 50.

32 R. Rubinkiewicz, "Apocalypse of Abraham,” OTP 1:681-705, at 685.

${ }_{33}$ Apoc. Ab. 13:3-4: "And an impure bird flew down on the carcasses, and I drove it away. And the impure bird spoke to me." The reference to the impurity of the 'bird' 
pteromorphic angelological code of the Apocalypse of Abraham, which portrays Yahoel with the body of a griffin, Azazel's bird-like appearance signals his possession of an angelic form. This angelic shape appears to be compromised and soiled, which renders it impure. It is not entirely clear, in this context, if the term "impure bird" signifies the antagonist's compromised angelic status absolutely, or rather the impropriety of his wearing the angelic garment in the current moment.

\section{CONCLUSION}

It is now time to return to the motif of the special celestial garment found in the Apocalypse of Abraham, and the significance of this theme for the sacerdotal framework of the Slavonic pseudepigraphon. It is no accident that the promise of a mysterious garment to Abraham occurs in the very chapters of the apocalypse that represent the text's sacerdotal nexus-the conceptual crux that intends to bring its readers into the heart of the apocalyptic Yom Kippur ritual. In Apoc. Ab. 13 and 14, Abraham's celestial guide, Yahoel, appears to perform one of the central ordinances of the atoning ceremony, by means of which impurity is transferred to Azazel and dispatched into the wilderness. Consider, e.g., Yahoel's arcane address to Azazel:

Reproach is on you, Azazel! Since Abraham's portion is in heaven, and yours is on earth, since you have chosen it and desired it to be the dwelling place of your impurity. Therefore the Eternal Lord, the Mighty One, has made you a dweller on earth. And because of you [there is] the wholly-evil spirit of the lie, and because of you [there are] wrath and trials on the generations of impious men. Since the Eternal Mighty God did not send the righteous, in their bodies, to be in your hand, in order to affirm through them the righteous life and the destruction of impiety...Hear, adviser! Be shamed by me, since you have been appointed to tempt not to all the righteous! Depart from this man! You cannot deceive him, because he is the enemy of you and of those who follow you and who love what you desire. For behold, the garment which in heaven

betrays the connection to the scapegoat figure, who, in the materials pertaining to the Yom Kippur ritual, is understood as an impure entity, a sort of a 'gatherer' of pollution which contaminates anyone who comes in contact with him-including his handlers, who must perform purification procedures after handling the goat. Jacob Milgrom observes that Azazel was "the vehicle to dispatch Israel's impurities and sins to wilderness/netherworld." Leviticus 1-16 (AB 3; New York: Doubleday, 1991), 1621. 
was formerly yours has been set aside for him, and the corruption which was on him has gone over to you. (Apoc. Ab. 13:7-14)

This address-which the celestial cultic servant of the highest rank delivers to the demoted angel who bears the name of the scapegoatis ritually significant, because it appears to reflect some of the actions of the high priest on Yom Kippur. For this reason, the phrase "dwelling place of your impurity" is especially intriguing. It alludes to the purgative function of the scapegoat ceremony, which centered on the removal of the impurity heaped on the sacrificial animal to the "dwelling place" of the demon in the wilderness. The corruption of Abraham, the forefather of the Israelite nation, is now transferred to Azazel. ${ }^{34}$ Yahoel appears to perform the so-called "transference function"-the crucial part of the scapegoat ritual-when the high priest passes Israel's sins onto the scapegoat's head through confession and the laying-on of hands. ${ }^{35}$ This, it seems, may also explain why Yahoel's speech contains a command of departure (Apoc. Ab. 13:12: “Depart from this man!") rather like the dispatch-formula given to the scapegoat in $m$. Yoma 6:4: "Take our sins and go forth." 36

In this climatic point of the apocalyptic Yom Kippur ceremony, Abraham's infamous opponent, stripped of his lofty celestial clothes, takes on a new, now sacrificial role in the principal purifying ordinance of the Jewish tradition by assuming the office of the cosmic scapegoat who is predestined to carry the celebrant's impurity into the netherworld. This mysterious burden of the ambiguous sacrificial agent, dispatching its ominous gift not to the divine, but to the demonic realm has puzzled generations of interpreters who often wondered if this oblation was a sacrificial portion to the Other Side. Thus, in the Book of Zohar and some later Jewish mystical writings the scapegoat

${ }^{34}$ Helm ("Azazel in Early Jewish Tradition," 223) sees in this utterance a connection to the Yom Kippur settings by proposing that "the transference of Abraham's corruption to Azazel may be a veiled reference to the scapegoat rite." Similarly, Grabbe ("The Scapegoat Tradition: A Study in Early Jewish Interpretation," 157) argues that the phrasing in the statement that "Abraham's corruption has 'gone over to' Azazel suggest[s] an act of atonement."

${ }^{35}$ Lev 16:21-22: "Then Aaron shall lay both his hands on the head of the live goat, and confess over it all the iniquities of the people of Israel, and all their transgressions, all their sins, putting them on the head of the goat, and sending it away into the wilderness by means of someone designated for the task. The goat shall bear on itself all their iniquities to a barren region; and the goat shall be set free in the wilderness." On the "transference" function, see also Milgrom, Leviticus 1-16, 1041.

${ }^{36}$ Fletcher-Louis, "The Revelation of the Sacral Son of Man," 282. 
was often understood as "the principal offering that is destined in its entirety for 'the Other Side." "37 In light of these later traditions it is not entirely impossible that in the dualistic framework of the Slavonic apocalypse where the antagonist's abode imitates the realm of the deity one can have such peculiar understanding of the scapegoat's functions. But this is the subject for another lengthy investigation.

${ }^{37}$ I. Tishby, The Wisdom of the Zohar (3 vols; Oxford: Oxford University Press, 1989), 2:821. 